\title{
Geochronological reconsideration of the eastern European key loess section at Stayky in Ukraine
}

\author{
A. Kadereit and G. A. Wagner \\ Heidelberger Lumineszenzlabor, Geographisches Institut, Universität Heidelberg, Im Neuenheimer Feld 348, \\ 69120 Heidelberg, Germany \\ Correspondence to: A. Kadereit (annette.kadereit@geog.uni-heidelberg.de)
}

Received: 22 April 2013 - Published in Clim. Past Discuss.: 22 May 2013

Revised: 18 February 2014 - Accepted: 28 February 2014 - Published: 24 April 2014

\begin{abstract}
Event-stratigraphical correlations between regional terrestrial sedimentary archives and marine or ice-core records that provide climate history are highly desirable for a deeper understanding of the effects of global climate change. However, such correlations are not simple, as the terrestrial records tend to be floating and fragmentary, and usually show varying sedimentation rates. Therefore, a reliable chronometric framework is a prerequisite for any event stratigraphy involving terrestrial archives. We propose that the age model underlying the event-stratigraphical approach for the eastern European key loess section at Stayky in Ukraine needs revision. Here we explore why it is unlikely that the Middle Pleniglacial Vytachiv Soil developed during Greenland interstadial (GIS) 8, and why the embryonic soils in the upper part of the Upper Pleniglacial part of the loess section most likely post-date the Heinrich 2 event. As a consequence, the revised age-model challenges the earlier suggested correlation of the suite of incipient soils above the Vytachiv Soil with Greenland Interstadials, which was supposed to start with GIS7 but for which matching from after GIS5 seems more likely. The revised chronology suggests that the transition from Middle to Upper Pleniglacial environmental conditions at the eastern European key section occurred during the final phase of marine isotope stage (MIS) 3. Thus, the picture appears to be in accordance with that of the western European key section at Nussloch. This points to a common driver of palaeo-environmental change in both regions, such as early late glacial maximum (LGM) advances of the Arctic ice shield or changes of the North Atlantic circulation and sea-ice distribution associated with changes in the palaeowind field relevant to aeolian loess deposition and soil
\end{abstract}

formation. To test and substantiate the alternative age model, more chronologies for well-stratified loess sections throughout the European loess belt are required.

\section{Introduction}

Loess-palaeosol sequences are important archives recording and storing the environmental history of terrestrial landscapes (e.g. Marković et al., 2009; Buggle et al., 2009). Over the last decades, loess-palaeosol sections covering the last glacial-interglacial cycle were studied intensively from western to eastern Europe (e.g. Antoine et al., 2001; Rousseau et al., 2011). For the younger glacial deposits, a stratigraphic bisection of loess deposits, with less intensively developed palaeosols covering loess deposits with more intensively developed palaeosols, earlier described by Schönhals et al. (1964), was well-supported (e.g. Antoine et al., 2001; Rousseau et al., 2001; Fuchs et al., 2008). Ideally, the lower part of a bisected loess deposit is terminated by a well-recognisable palaeosol, regionally called the Lohne Soil (Germany, Austria), Vytachiv Soil (Ukraine), Surduk Soil (Serbia), etc., which at the top is truncated due to discordant erosion. Thus, the terminal palaeosol may function as a pedostratigraphic marker horizon (cf. Semmel, 1995; Zöller and Semmel, 2001; Terhorst et al., 2001; Wagner, 2011) for large-scale stratigraphic correlation of loess sections. The significant change in the pedosedimentary stratigraphy indicates corresponding changes in the palaeo-environmental conditions of the respective terrestrial landscapes during the milder climate excursions of the last glacial period 


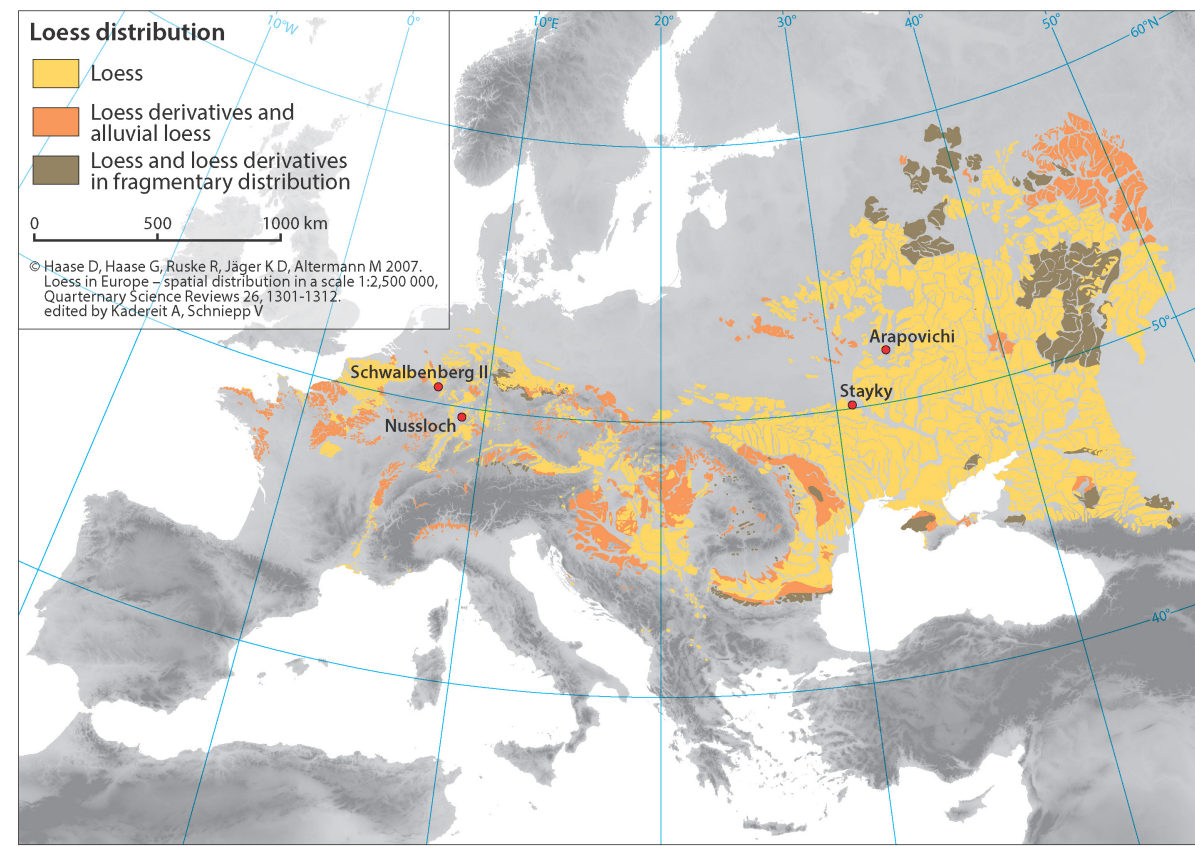

Fig. 1. Location of the well-developed loess sections Nussloch (key section for western Europe), Schwalbenberg II, Stayky (key section for eastern Europe) and Arapovichi within the European loess belt (map based on Haase et al., 2007).

(Dansgaard-Oeschger warm events or Greenland interstadials, GIS, respectively) which show a recurrence interval of ca. 1500 years and during which soils are assumed to develop (e.g. Schulz, 2002; Rousseau et al., 2002). This marked change is attributed to the transition from the Middle to the Upper (Younger) Wurmian ("Mittelwürm" to "Jungwürm" after Schönhals et al., 1964), following the original terminology, or to the Weichselian Middle to Upper Pleniglacial boundary (e.g. Antoine et al., 2009), following the modern stratigraphic classification for western and northern Europe (e.g. Törnqvist et al., 2000; van Huissteden and Kasse, 2001). Therefore, the marker horizon indicates a time after which environmental conditions changed significantly throughout Europe.

Environmental changes for the Middle Pleniglacial to Upper Pleniglacial transition are best reconstructed at sections which show the smallest chronometric gap between a preserved uppermost Middle Pleniglacial (MPG) soil and a preserved lowermost Upper Pleniglacial (UPG) loess deposit. In this respect, a site like Nussloch (e.g. Antoine et al., 2009) with apparently little truncation of the MPG is preferable to the Dolní Věstonice (DV09) section in the Czech Republic (Antoine et al., 2013) or the Ostrau section in eastern Germany (Kreutzer et al., 2012), where MPG parts were eroded down to ca. $45 \mathrm{ka}$ or even ca. $70 \mathrm{ka}$ old deposits, respectively. In the most complete sections, the marked transition in the terrestrial archives occurred somewhere near the transition from marine isotope stage (MIS) 3 to MIS2 (e.g. Antoine et al., 2009; Schirmer, 2012). However, it should be noted that the MPG-UPG boundary was variably attributed to the termination of GIS3, that is, the MIS3-MIS2 boundary (e.g. Huijzer and Vandenberghe, 1998; Törnqvist et al., 2000; Guiter et al., 2003), or to the termination of GIS5, i.e. within the final phase of MIS3 (e.g. van Huissteden and Kasse, 2001).

Palaeopedological and stratigraphical investigations at the loess-palaeosol sections are currently accompanied by dating of the pedosedimentary archives. Dating determines the time when respective environmental conditions prevailed or changed at a site. It also clarifies whether the stratigraphically apparently matching terminal palaeosols developed at the same time, and whether environmental conditions changed isochronically at the different terrestrial locations. It is prudent to intensify such investigations at well-developed key sections, which each serve as a reference profile for a greater region. Thus, the Nussloch section in southwestern Germany, which contains a well-developed Lohne Soil, is regarded as a key section for western Europe (Antoine et al., 2009), while the section at Stayky in Ukraine which contains the Vytachiv Soil is regarded as a key section for eastern Europe (Rousseau et al., 2011; Figs. 1 and 2).

It is essential to develop especially reliable chronologies for the key sections, as results from these sites are routinely transferred to other sections to achieve a better understanding of their stratigraphy and chronometry. Only recently, the well-developed loess-palaeosol section Schwalbenberg II in the Middle Rhine valley in Germany (cf. Figs. 1 and 2) was compared with the Nussloch section (Schirmer, 2012). Following the Nussloch chronology, the upper two Middle Pleniglacial palaeosols at the Schwalbenberg II section 


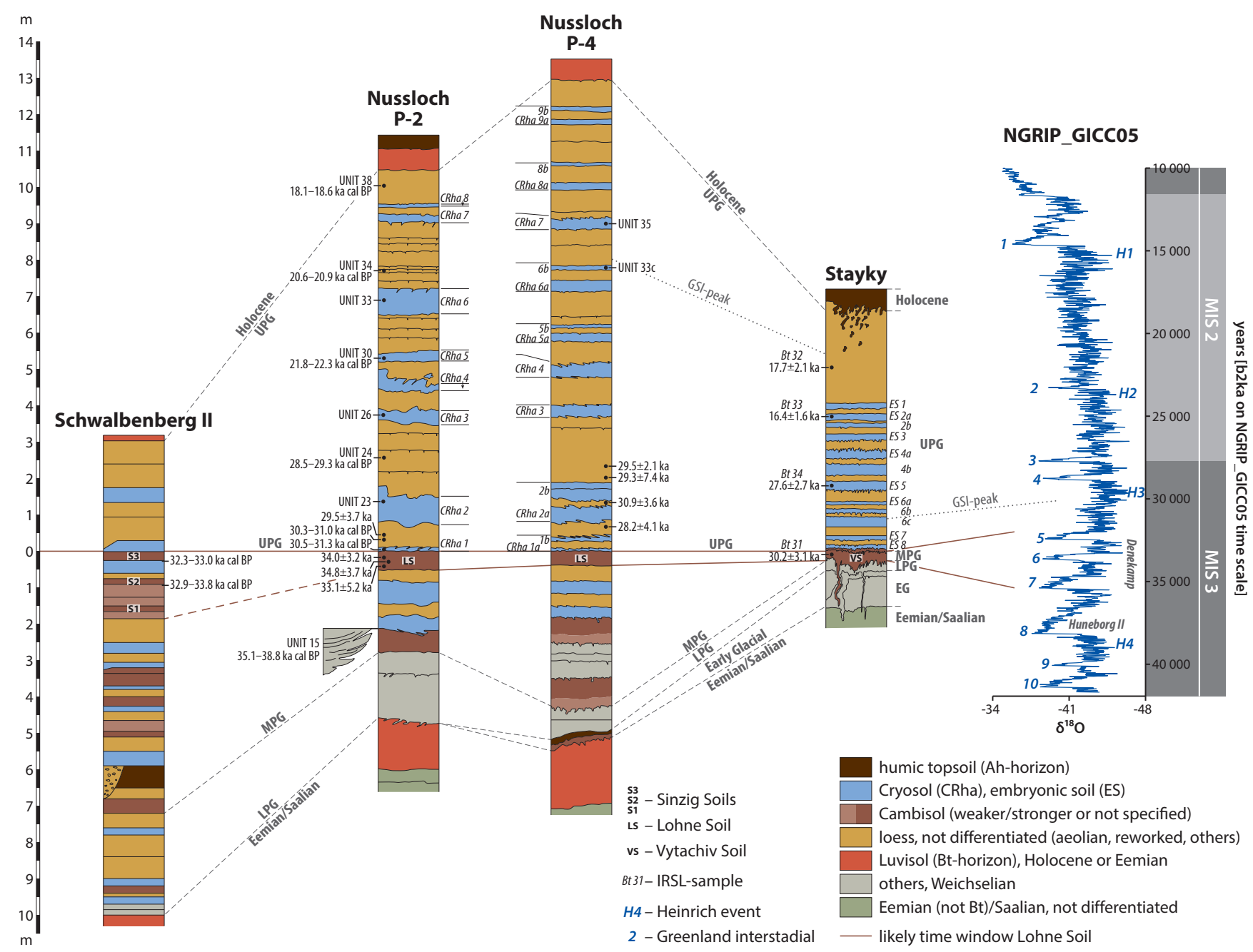

Fig. 2. Simplified sketches of the loess sections Schwalbenberg II (after Schirmer 2012), Nussloch (after Antoine et al., 2009) and Stayky (after Rousseau et al., 2011). Luminescence ages "age \pm error" ka, $1 \sigma$, with reference to the year of publication. ${ }^{14} \mathrm{C}$ age ranges "age - age ka cal BP”, $1 \sigma$, with reference to 1950 AD. Calibration CalPal-2007HULU (Weninger et al., 2012). NGRIP_CiCC05 timescale after Andersen et al. (2006) and Svensson et al. (2006), with reference to 2000 AD. Nussloch presented with luminescence ages from around LS (unit 20, after Antoine et al., 2009) and ${ }^{14} \mathrm{C}$ ages from samples evaluated as especially reliable by Antoine et al. (2009). Age range 38 750-35 130 a cal BP for thermokarst infilling (unit 15, after Antoine et al., 2009) based on ${ }^{14} \mathrm{C}$ ages from ten wood samples matching time window for GIS8 on NGRIP_CICC05 timescale ca. 38 300-35 500 a b2k (cf. compilation of ${ }^{14}$ C ages in Kadereit et al., 2013, Fig. S2 in the Supplement: lower age boundary sample ETH-21511 (33040, 440); upper age boundary sample GIF/LSM-10442 (31 800, 400$)$ ). Time window around uppermost MPG soil stratigraphically apparently best resolved at the Schwalbenberg II section (three individual soils, S1-S3). Correlation of S2 with GIS6 and S3 with GIS5, respectively, as suggested by ${ }^{14} \mathrm{C}$ dating at the site and time windows of GIS6 and GIS5 within the NGRIP_CICC05 timescale (cf. Fig. S2 in the Supplement).

(Sinzig Soils, S2 and S3) were correlated with GIS7 (S2) and GIS6 (S3), although ${ }^{14} \mathrm{C}$ dating at the site itself would allow their correlation with GIS6 (S2) and GIS5 (S3) (cf. Figs. S1 and $\mathrm{S} 2$ in the Supplement). Therefore, it cannot be excluded that possible misinterpretation of a key section might lead to incorrect interpretation of other loess-palaeosol sections elsewhere. This can be avoided by re-evaluating the data of the key sections as scientific knowledge progresses.

In recent years, ${ }^{14} \mathrm{C}$ and luminescence dating has brought about a wealth of chronometric data for important loess sections (Fuchs et al., 2013; Haesaerts et al., 2010; Terhorst et al., 2011; Stevens et al., 2011; Timar et al., 2010; and many more). But methodological progress in dating techniques has shown also that ${ }^{14} \mathrm{C}$ ages beyond ca. $35^{14} \mathrm{C}$ ka BP, corresponding to ca. $40 \mathrm{kacal} \mathrm{BP}$, might have to be interpreted carefully (e.g. Briant and Bateman, 2009). This holds especially for ages that were determined from bone collagen or charcoal, which tend to underestimate true ages, unless samples were subject to special pretreatment (e.g. Higham, 2011). For a comprehensive review of that topic refer to 
Talamo et al. (2012). It has also been argued that ${ }^{14} \mathrm{C}$ dating of loess organic matter may underestimate the age of loess deposition, if post-sedimentary contamination with younger organic matter occurred by deep rooting plants (e.g. Wiesenberg et al., 2014). Luminescence dating, too, has shortcomings. Apart from age overestimation due to incomplete bleaching of the latent luminescence signal prior to sediment deposition, age underestimation is also possible. This was reported for infrared-stimulated luminescence (IRSL) dating of feldspars or the feldspar component of polymineral fine grains, respectively, if measurements were performed using inadequate detection filters focusing on or including, for example, an unstable UV emission (e.g. Lang and Wagner, 1996; Wallinga et al., 2000). As a consequence, such measurements require procedures for age correction which may generate undesirably large age errors (e.g. Vasiliniuc et al., 2013). But also a carefully chosen measurement set-up, including a narrow detection window focusing, for example, on the stable blue feldspar emission around $410 \mathrm{~nm}$ (Krbetschek et al., 1996) and a stronger preheating, can produce IRSL ages which are suspicious of underestimating the true ages by ca. $3 \mathrm{ka}$ for ca. $30 \mathrm{ka}$ old samples (Lomax et al., 2012). Although midpoints of the IRSL ages of the latter study tended to be slightly too low, the expected ages were met within error margins $(1 \sigma)$ and do not deliver erroneous results. This finding is relevant for the interpretation of IRSL ages in the present study (see Sect. 3).

Rapid progress in the dating of terrestrial sediment archives presently allows matching of the local and regional terrestrial archives with marine and ice-core records (e.g. Antoine et al., 2009; Rousseau et al., 2011). Such correlations are relevant, as the latter are regarded to record the global climate signals. Thus they may be interpreted to reflect the pacemaker of environmental change in the local and regional palaeo-landscapes, as documented in the terrestrial pedosedimentary archives. The resolution and understanding of the global records are also improving (cf. Fig. 3 and literature quoted therein), requiring a re-evaluation of earlier correlations between them and the terrestrial archives.

A recent re-evaluation of the western European key section at Nussloch has led to a modified interpretation of the chronology revealing that the likely period for the evolution of the Lohne Soil matches GIS7-GIS5 (Kadereit et al., 2013). This interpretation is in accordance with an alternative interpretation of the Schwalbenberg II chronology for the time period close to the MIS3-MIS2 boundary (cf. Fig. S1 in the Supplement). Another outcome of the Nussloch study was that the MPG-UPG boundary as observed in the western European loess-palaeosol section does not seem to conform to the MIS3-MIS2 transition. Rather, it appears that the western European terrestrial environment responded earlier, i.e. immediately after the termination of GIS5.

Because the eastern European key section at Stayky in Ukraine was correlated with the Nussloch section (Rousseau et al., 2011), we here reinvestigate the stratigraphic and chronometric data available for the Ukrainian key section. For our study we revert to data published by Rousseau et al. (2011) in Climate of the Past (Vol. 7, 221-234). Our aim is to determine whether earlier interpretation of the Stayky chronology is robust or whether it needs adjustment in light of new consideration.

\section{Data and philosophy}

Rousseau et al. (2011) constructed a palaeowind-strength record for the Stayky loess section in Ukraine, using, as a proxy, a ratio of coarse silt to fine and medium silt plus clay, the so-called grain-size index $\left(\mathrm{GSI}^{1}\right)$. This proxy record was correlated with the GSI record from the western European key loess section at Nussloch (Antoine et al., 2001, 2009). Both terrestrial records were correlated with the global ice-core timescale GRIP_ss09sea (Johnsen et al., 2001) (cf. Fig. 3e) and a dust record for the Greenland ice core, most likely based on Ruth et al. (2002, 2003) and Ruth (2005). Matching occurred with an eventstratigraphical approach based on visual similarity between records. GSI values increase with wind strength. Cool Greenland stadials and cold Heinrich events are associated with periods of high and very high wind strength, respectively, while the warmer Greenland interstadials are periods of low wind strength. Likewise, colder periods are associated with loess accumulation, while warmer periods are times of soil formation. This allowed to recognize millennial-scale Dansgaard-Oeschger events to be recorded and archived in loess-palaeosol sequences (cf. Rousseau et al., 2002). The event-stratigraphical approach resulted in the correlation of a suite of embryonic soils (ES1 to ES8) in the upper part of the Stayky profile between ca. $630 \mathrm{~cm}$ and $230 \mathrm{~cm}$ b.g.l. (below ground level) with GIS7 to GIS2, based on the assumption that the underlying Vytachiv Soil at ca. $650 \mathrm{~cm}$ b.g.l. matches GIS8. But such a correlation is not supported by the chronometric data provided by Rousseau et al. (2011).

A necessary prerequisite for the event stratigraphy is a solid chronometrical framework, to place the part of the terrestrial loess record that shall be correlated with the global ice-core record in the most likely time window. This is essential as the terrestrial records are usually neither complete nor continuous and they do not show constant sedimentation rates. Instead, the terrestrial pedosedimentary archives are floating, likely exhibiting stratigraphical gaps and varying sedimentation rates along the time axis. Therefore, the placement of the time markers is most essential and has to be carried out with special care.

For the Stayky loess sequence, Rousseau et al. (2011) provide four infrared stimulated luminescence (IRSL) ages. These serve as the necessary chronometric tie points. The

\footnotetext{
${ }^{1}([63.4-20.7 \mu \mathrm{m}] /<20.7 \mu \mathrm{m})$ for Stayky (Rousseau et al., 2011); $[50-20 \mu \mathrm{m}] /<20 \mu \mathrm{m}$ respectively $[52.6-26 /<26 \mu \mathrm{m}]$ for Nussloch (Antoine et al., 2009).
} 


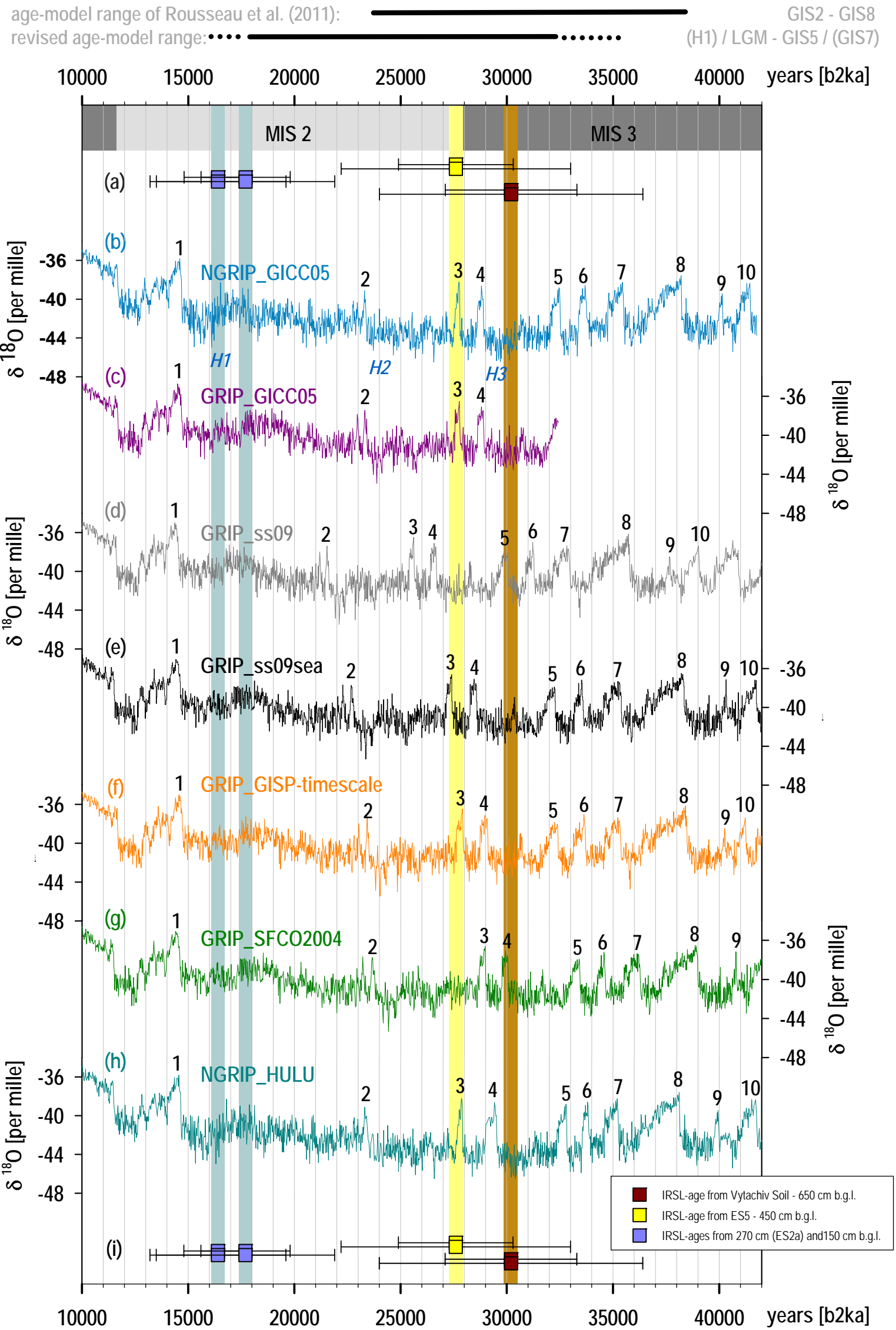

Fig. 3. Caption on next page. 
Fig. 3. IRSL chronology for the loess section at Stayky, Ukraine, reflected in global ice-core timescales. The age model of Rousseau et al. (2011) starts with GIS8 for the Vytachiv Soil, and terminates prior to Heinrich 2 for the uppermost embryonic soil ES1 (early and short chronology). The IRSL data, however, cover an age range from GIS5 (GIS7 at the utmost on a $2 \sigma$ error range) to the late LGM during the second half of the Greenland stadial between GIS2 and GIS1 (later and longer chronology). Please note that for Fig. 3 data were taken from Figs. 3 and 4 of Rousseau et al. (2011), which tend to be slightly older than the data given in Table 1 of the same publication, and which have significantly larger errors than the table values. For recent criticism on the CICC05 timescale - with respect to a bias towards younger ages of few hundred years especially between GIS2 and GIS6 and to the placement of Heinrich events, which in the marine timescales usually directly precede the beginning of a GIS as documented in respective debris layers - see Skinner (2008). Therefore, the positions for H1-H3 in Fig. $3 \mathrm{~b}$ should be regarded as tentatively designated, meant only as an aid to follow our argumentation. (a) IRSL ages after Rousseau et al. (2011, Figs. 3 and 4). The data in the figures tend to be slightly older and they have larger errors than the ages given by the authors in Table 1. (b)-(f) Data from the Centre for Ice and Climate, Niels Bohr Institute, University of Copenhagen: http://www.iceandclimate.nbi.ku.dk/; the $\delta^{18} \mathrm{O}$ data are as based on Dansgaard et al. (1993), GRIP Members (1993) and Johnsen et al. (1997) (for more details see below). (b) North Greenland Ice Core Project (NGRIP) with Greenland Ice Core Chronology 2005 (GICC05) (Andersen et al., 2006; Svensson et al., 2006) released 10 September 2007; file name "GICC05_NGRIP_20y_10sep2007"; the NGRIP data for the time window of 10 to $42 \mathrm{ka}$, as presented here, are all from core NGRIP2 only; (c) GRIP with Greenland Ice Core Chronology 2005 (GICC05) (Andersen et al., 2006; Svensson et al., 2006) released 27 November 2006; file name "GICC05_NGRIP_GRIP_20y_27nov2006"; prior to 11.7 ka the NGRIP_GICC05 timescale has been transferred to GRIP by the use of volcanic marker horizons and the linear interpolation in between Rasmussen et al. (2006, 2008). (d) ss09 timescale (Johnsen et al., 1995) released 23 November 2000 by I. A. Mogensen; file name "gripdelta.dat" (GRIP; oxygen isotopes; 20 years averages on GISP2 timescale; 375-103000 yr BP), columns 1-2. (e) ss09sea or GRIP2001 chronology (Johnsen et al., 2001); ASCII file (GRIP; oxygen isotopes; 20 year averages back to $122 \mathrm{kyr} \mathrm{BP).} \mathrm{(f)} \mathrm{GISP} \mathrm{timescale} \mathrm{as} \mathrm{based} \mathrm{on} \mathrm{Alley} \mathrm{et} \mathrm{al.} \mathrm{(1993),} \mathrm{Meese}$ et al. (1994) and Sowers et al. (1993) released 23 November 2000 by I. A. Mogensen; file name "gripdelta.dat" (GRIP; oxygen isotopes; 20 years averages on GISP2 timescale; 375-103000 yr BP), columns 2-3. (g) Data of SFCO2004 timescale from the Pole-Ocean-Pole Project, Department of Earth Sciences, University of Cambridge: http://www.esc.cam.ac.uk/research/research-groups/pop/pop-project-data/ pop-project-grip-data-on-sfcp2004-timescale; file name "GRIP data on SFCP2004 timescale"; the SFCP2004 timescale (Shackleton et al., 2004) is based on the matching between the GRIP $\delta^{18} \mathrm{O}$ record and the $\delta^{18} \mathrm{O}$ record of planktonic foraminifera of piston core MD95-2042 (Shackleton et al., 2000) that is ${ }^{14} \mathrm{C}$ dated by the use of a correction curve based on paired ${ }^{230} \mathrm{Th} /{ }^{234} \mathrm{U} /{ }^{238} \mathrm{U}$ and ${ }^{14} \mathrm{C}$ dates on pristine coral samples (Fairbanks et al., 2005). (h) Greenland-Hulu U/Th timescale: Greenland NGRIP stable oxygen isotope record from Andersen et al. (2006)) and Svensson et al. (2006, 2008) tuned to the Hulu Cave U/Th chronology and $\delta^{18}$ O stratigraphy from Wang et al. (2001). Data record from Weninger and Jöris (2008). (i) like (a).

results of the dating are presented by the authors in Table 1 and Figs. 3 and 4, but they differ slightly in the figures as compared to the table. The samples (from bottom to top) BT 31, BT 34, BT 33 and BT 32 from 650, 450, 270 and $150 \mathrm{~cm}$ b.g.l. yielded ages of $30.1 \pm 2.3 \mathrm{ka}^{2} / 30.2 \pm 3.1 \mathrm{ka}^{3}$, $27.6 \pm 2.0 \mathrm{ka}^{2} / 27.6 \pm 2.7 \mathrm{ka}^{3}, \quad 16.4 \pm 1.2 \mathrm{ka}^{2} / 16.4 \pm 1.6 \mathrm{ka}^{3}$ and $17.6 \pm 2.0 \mathrm{ka}^{2} / 17.7 \pm 2.1 \mathrm{ka}^{3}$. The ages vary mainly in the given errors which are mostly about $30 \%$ larger in the figures, as compared to the table. We assume that the ages are quoted on the $1 \sigma$ error level, which is usual practice for luminescence dating.

\section{Results and discussion}

The ages for the samples from 270 and $150 \mathrm{~cm}$ are identical within error margins, with the midpoints showing slight age inversion. This means that sedimentation rates in the upper part were probably too high for sufficient chronometric resolution with luminescence dating. The most important time marker is the IRSL age for sample BT 31, which is from the horizon of the Vytachiv Soil. Rousseau et al. (2011) argue that the chronometry supports a correlation of the Vytachiv

\footnotetext{
${ }^{2}$ Data from Table 1 of Rousseau et al. (2011).

${ }^{3}$ Data from Figs. 3 and 4 of Rousseau et al. (2011).
}

Soil at the Stayky loess site in Ukraine with the Lohne Soil at Nussloch in southwestern Germany (for a recent review on the Nussloch section see Antoine et al., 2009). They argue further that the chronometry supports a correlation of the Vytachiv Soil with GIS8. However, for the Nussloch site Kadereit et al. (2013) showed that a correlation of the Lohne Soil with GIS8 must be excluded. The possible chronometric time window for the palaeosol formation at Nussloch is GIS7 to GIS5. Further stratigraphical considerations point to GIS5 as a likely period, in which the Lohne Soil developed, or rather reached its climax state, in the likely case that soil development had commenced already during the preceding or the two preceding Greenland interstadials.

Luminescence dating determines the time when a mineral grain was last exposed to daylight. Therefore, luminescence ages for samples from soil horizons do not determine the time of soil formation, but the time (cold and windy stadial) when the sediment (loess) was deposited prior to the time when the soil developed therein (subsequent warm and less windy interstadial). Thus, IRSL dating determines the Greenland stadial before the Greenland interstadial, which matches the period of soil formation. If, however, bioturbation is significant during the period of soil formation, mineral grains may be bleached sufficiently to determine the time of soil formation (e.g. Kadereit et al., 2010). If the Vytachiv Soil 
matches GIS8, as proposed by Rousseau et al. (2011), the IRSL age for sample BT 31 should correspond either to the Greenland stadial ${ }^{4}$ between GIS9 and GIS8 (no bioturbation or other post-depositional bleaching of mineral grains), or to GIS8 (sufficient bleaching during the period of soil formation). In order to test this hypothesis, we compiled the most commonly used global ice-core timescales and plotted them together with the IRSL age for sample BT 31 in Fig. 3. The GRIP_ss09 timescale (Johnsen et al., 1995) (Fig. 3d) is regarded as inadequately calibrated to calendar years, as it lacked necessary corrections for $\delta^{18} \mathrm{O}$ variations of the ocean water, which were applied later and published as the GRIP_ss09sea timescale (Johnsen et al., 2001) (Fig. 3e). For the correlation of palaeorecords in the period $15-42 \mathrm{ka}$, the INTIMATE group recommended to use the NGRIP_CICC05 timescale (Andersen et al., 2006; Svensson et al., 2006) as the relevant standard timescale (Hoek et al., 2008) (Fig. 3b). Therefore, we included Heinrich events (H1-H3) on the NGRIP_CICC05 timescale in Fig. 3b, at least tentatively. We did not use the IRSL age as presented in Table 1 of Rousseau et al. (2011), but used the slightly older age with the larger error as given in Figs. 3 and 4 of that publication. This way, we avoid biasing the data to better suit our arguments. We plotted the IRSL age both with the $1 \sigma$ and the $2 \sigma$ error bars, respectively. On the $1 \sigma$ error level, the age covers the period 27.1-33.3 ka (brown squares with shorter error bars in Fig. 3a and i), on the $2 \sigma$ error level it covers the period 24.0$36.4 \mathrm{ka}$ (brown squares with longer error bars). From Fig. 3 it becomes clear that the age model for the Vytachiv Soil does not include GIS8 - unless one refers to the obsolete GRIP_ss09 timescale and argues on the $2 \sigma$ error level. The IRSL age for the level of the Vytachiv Soil covers at maximum GIS7 $(2 \sigma)$, while a later period (GIS5) is the more likely period on the $1 \sigma$ error level. Therefore, a start of the event stratigraphy for the suite of embryonic soils with GIS7 as proposed by Rousseau et al. (2011) is not supported by the chronometry. Based on the IRSL dating of the underlying Vytachiv Soil, the lowermost embryonic soil (ES8) in the hanging wall could post-date GIS5 or correspond to the descending slope of GIS5. It is interesting to note that this interpretation would correspond to the independently revised age model and correlation of palaeosols with Greenland interstadials as suggested for the Nussloch site by Kadereit et al. (2013), if one accepts a correlation between the Lohne Soil and the Vytachiv Soil, as suggested by Rousseau et al. (2011). The IRSL age of sample BT 31 could also point to soil formation during GIS4 and/or GIS3. This interpretation, however, is unlikely, when the dating result for sample BT 34 is taken into account.

The IRSL age for BT 34 from $450 \mathrm{~cm}$ b.g.l. originates from ES5. As embryonic soil number 6 occurs threefold

\footnotetext{
${ }^{4}$ As there exist differing systems for the numbering of Greenland stadials (e.g. Björk et al., 1998 versus Rousseau et al. 2006), we address a respective stadial as "a stadial between GIS $\#$ and GIS $\#-1$ ”).
}

(ES6c-ES6a), ES5 is the sixth embryonic soil detected above the Vytachiv Soil. For ES6c a positive excursion of the GSI record is observed (Fig. 4 of Rousseau et al., 2011), which the authors attribute to Heinrich 3 event. As Heinrich 3 dates around $31 \mathrm{ka}$ (Hemming, 2004; Skinner, 2008) just predating GIS4, this would conform to a formation of the Vytachiv Soil at Stayky during (or until) GIS5. On the $1 \sigma$ error level, ES5 could match GIS4 or GIS3 (see yellow squares with short error bars for BT 34 in Fig. 3a/i). If this interpretation is accepted, the lowermost five embryonic soils represent the final part of MIS3 (i.e. the period post-dating GIS5). MIS3, and oxygen isotope stage (OIS) 3, respectively, end with the termination of GIS3 (e.g. Anderson et al., 2006). As mentioned above, the Middle to Upper Pleniglacial boundary for terrestrial archives has been variably defined, either corresponding to the termination of GIS3 (e.g. Törnqvist et al., 2000; Pirson et al., 2012), so that the Middle Pleniglacial compares to MIS3, or to the peak of GIS5 (cf. van Huiststeden and Kasse, 2001). Considering the remarkable change from a Middle Pleniglacial to an Upper Pleniglacial habitus of the loess-palaeosol sequence at the top of the Vytachiv Soil, as documented by Rousseau et al. (2011), the latter scheme appears more appropriate for the Stayky section. Otherwise, the MPG-UPG boundary would have to be placed further up in the Stayky profile than proposed by Rousseau et al. (2011, Fig. 4), either between ES5 and ES4b, or further up in the hanging wall. However, it does not seem wise to obtrude marine and ice-core schemes onto terrestrial archives. Rather it is worth noticing that the regional terrestrial pedosedimentary archive does not seem to accord to the global archive.

Whether or not ES5 post-dates Heinrich 3, as suggested by Rousseau et al. (2011) cannot be decided on the $1 \sigma$ error level of the chronometric data, as the error range of BT 34 includes the time period of Heinrich 3. Yet, it is likely if one follows the above interpretation that the formation of the $\mathrm{Vy}-$ tachiv Soil matches GIS5 and ES5 matches GIS3 or GIS4.

Heinrich 2 dates around $24 \mathrm{ka}$ (Hemming, 2004; Skinner, 2008), a period which is not adequately resolved by the IRSL record. The next to uppermost embryonic soil (ES2a) at $270 \mathrm{~cm}$ b.g.l. yields an age of around $16.4 \mathrm{ka}$, which could correspond to the time of Heinrich 1 event (cf. Hemming, 2004; Skinner, 2008), or to the late glacial maximum (LGM). ${ }^{5}$ A similar age of $17.7 \pm 2.1 \mathrm{ka}$ was found for sample BT 32 from $150 \mathrm{~cm}$ b.g.l., supporting a likely LGM age for the upper half of the Stayky profile (both IRSL ages in Fig. 3a and $i$ as light blue squares). In contrast to that, Rousseau et al. (2011) attribute a GSI peak ca. $150 \mathrm{~cm}$ b.g.l. to Heinrich 2

\footnotetext{
${ }^{5}$ Here we define the LGM, not as sometimes done for ice-core records, i.e. as the stadial period of minimum $\delta^{18} \mathrm{O}$ values between GIS3 and GIS2 ca. 27.5-23.5 ka before present (e.g. Svensson et al., 2006), but as appropriate for European loess-palaeosol archives, i.e. as the time after Heinrich 2 event until the onset of termination 1 ca. 21-18 ka BP (cf. also "LGM sensu lato" in Sommer and Zachos, 2009 and considerations in Kadereit et al., 2013).
} 
event. Therefore, the necessary chronometric backbone for the event stratigraphy seems to be disregarded. It is noteworthy that the new interpretation is supported independently by the Nussloch chronology and a GSI correlation between the two loess sections at Stayky and Nussloch. Thus, Rousseau et al. (2011) compare the GSI peak at ca. $150 \mathrm{~cm}$ b.g.l. at Stayky with a GSI peak between gley/CRha ${ }^{6} 6 \mathrm{~b}$ (unit 33c) and gley/CRha 7 (unit 35) at Nussloch (cf. Fig. 2). The chronometry at Nussloch is supported for unit 34 and unit 38 by ${ }^{14} \mathrm{C}$ data, which are considered as especially reliable by Antoine et al. (2009). These data place gley/CRha 5 to gley/CRha 8 from Nussloch in the LGM period ca. 21$18 \mathrm{ka} \mathrm{BP}^{7}$, clearly post-dating Heinrich 2 event (cf. Fig. 6 in Kadereit et al., 2013). If the level of ca. $150 \mathrm{~cm}$ b.g.l. at the Stayky section corresponds to the GSI peak just below gley/CRha 7 at the Nussloch section, as suggested by Rousseau et al. (2011, Fig. 4), the upper part of the Stayky loess section should correspond to the cold stadial between Heinrich 2/GIS2 and Heinrich 1/GIS1, and would not predate Heinrich 2. Therefore, the Stayky event stratigraphy seems to be questionable, both in its lower and in its upper part, where the IRSL chronometry is not sufficiently considered. The discrepancies could be partly due to the inferior temporal resolution of the Ukrainian loess section (only ca. $4.5 \mathrm{~m}$ vertical resolution of the Weichselian pedosedimentary archive between the Vytachiv Soil and the uppermost embryonic soil (ES1) at Stayky as compared to ca. $10-12 \mathrm{~m}$ between the Lohne Soil and gley/CRha 8/9b at Nussloch (cf. Fig. 2). Further problems with a dust-event stratigraphy may be caused by a possibly distorted, non-linear time axis due to varying sedimentation rates. Events in the ice-core records show relatively undistorted peaks, as the timescales are reasonably well calibrated to calendar years. For visual correlation with the global record, however, the different sections of the terrestrial record are manually variably squeezed or stretched (cf. Fig. 7 of Rousseau et al., 2011). The same holds for an event stratigraphy between two loess-palaeosol records, which for the visual correlation are manually adapted in profile length (i.e. along the time axis). Therefore, the occurrence and size of events in the terrestrial record is partly a result of the pretreatment of the data record. The a priori placement of time markers and the application of computeraided and statistically supported wiggle-matching or other

\footnotetext{
${ }^{6}$ According to IUSS Working Group (WRB, revised edition, 2007) the Pleniglacial tundra-soil remains at Nussloch are mostly Haplic Cryosols (Reductaquic, Siltic). The recommended code for the soil reference group and the prefix qualifier is "CRha".

${ }^{714} \mathrm{C}$ data for sample GifA-99014 from unit 34 (3.8 m b.g.l.) and for GifA-96221 from unit 38 (1.6 m b.g.1.) at the Nussloch loess section are $17250 \pm 140{ }^{14} \mathrm{C} \mathrm{BP}$ and $15260 \pm 110^{14} \mathrm{CBP}$, respectively (Hatté et al., 2001). These correspond to 21 160-20 140 and 18 750-18040 cal BP, respectively (95.4\%) (OxCal 4.1, Bronk Ramsey, 2012; IntCa109, Reimer et al., 2009). (Cf. almost identical ages in Fig. 2, based on calibration with CalPal-2007 ${ }_{\text {HULU, }}$ Weninger et al., 2012, $1 \sigma$ ).
}

procedures appropriate for time-series analysis could help to objectify such non-trivial correlation procedure.

In the original publication by Rousseau et al. (2011), the protocol used for luminescence dating was not detailed, which makes it difficult to judge the quality of the dating results. However, dating of the Stayky samples was performed in the established luminescence dating laboratory in Bayreuth, Germany. Multiple aliquot (MA) measurements were done detecting the blue feldspar emission around $410 \mathrm{~nm}$ using the glass filter combination of BG39, $2 \times$ BG3 and GG400 (Schott) as recommended by Krbetschek et al. (1996). In between sample irradiation and IRSL readout, samples were stored at room temperature for at least 4 weeks in the dark following Lang et al. (1996) and Mauz et al. (2002) or at $70^{\circ} \mathrm{C}$ for a minimum of one week following Berger (1987). Prior to IRSL readout, samples were preheated for $60 \mathrm{~s}$ at $270^{\circ} \mathrm{C}$ (information on measurement parameters by courtesy Ludwig Zöller/Bayreuth). Thus, precaution was taken to avoid anomalous fading. Several publications, both for TL and IRSL, had shown that observed signal losses reach a (measurable) standstill after either (1) sample storage at room temperature for several weeks (e.g. Lang, 1996; Necea et al., 2013) or (2) shorter storage at elevated temperature (e.g. Berger, 1987).

Equally important, however, is the choice of a suitable IRSL-detection window focusing on a stable feldspar emission, as, for example, the blue emission around ca. $410 \mathrm{~nm}$, which does not include any instable signal, as, for example, the $280 \mathrm{~nm}$ emission (e.g. Krbetschek et al., 1996; Lang, 1996). Considering these rules, with multiple aliquot additive (MAA) protocols, IRSL ages from a few ka to ca. $120 \mathrm{ka}$ may be gained, which are in agreement with independently derived ages (e.g. Lang, 1997; Rieser and Wang, 2011; Lang et al., 2003).

However, as no results from tests of anomalous fading of the IRSL signal were given for the Stayky chronometry, fading and therefore systematic age underestimation, though rather unlikely in view of the measurement protocol, cannot be definitely excluded. But assuming hypothetical age underestimation for the IRSL chronometry at Stayky, would not change the interpretation for the base of the suite of embryonic soils. As may be derived from Fig. 3, it would need a severe underestimation of at least ca. $2.5 \mathrm{ka}$ (missing difference for the $2 \sigma$ error bar to reach beyond the base of GIS8, i.e. into the stadial between GIS9 and GIS8) or even ca. $5.5 \mathrm{ka}$ ( $1 \sigma$ error bar) to justify on grounds of the chronometry a matching of the Vytachiv Soil with GIS8. Hypothesising such large age underestimation would outrange, for example, the slight discrepancies between IRSL finegrain ages and blue-light stimulated luminescence (BLSL) quartz ages as observed for the loess section at KremsWachtberg in Austria, where, however, the slightly lower IRSL ages were on the $1 \sigma$ error level still in agreement with the BLSL ages as well as with the ${ }^{14} \mathrm{C}$ age for the Palaeolithic find layer (Lomax et al., 2012). From this it follows that the 
IRSL ages probably give reasonably correct ages not leading to erroneous interpretation in the lower part of the Stayky loess section.

The situation is slightly different for the IRSL age for ES5. Slight age underestimation of 1 or 2 ka could place the embryonic soil before GIS3, or even before GIS4. Yet this would not change the general correlation of the lower embryonic soils with the final phase of MIS3, i.e. the period after GIS5. Therefore, the chronometric considerations suggest a trisection of the loess section containing the suite of embryonic soils, which places

1. ES8 to approximately ES5/ES4b into the final and still warmer/more humid MIS3,

2. approximately ES4b and ES4a into the more moderate early MIS2, and

3. approximately ES2a/ES1 or only the loess above to at least $150 \mathrm{~cm}$ b.g.l. into the cold and dry LGM towards the end of MIS2.

The general trend in decreasing temperature and humidity in the greater region from MIS3 to MIS2 is reflected by the pollen record of the Arapovichi loess section (Molodkov and Bolikhovskaya, 2009 and literature quoted therein; cf. Fig. 1). At Stayky, the trisection is not reflected by the pedosystem, which - compared to the millennial-scaled climate oscillations - seems to possess relatively long reaction and relaxation times as well as long times to reach a respective climax stadium. All the observed soils were addressed uniformly as incipient or embryonic soils and the LGM period above ca. $230 \mathrm{~cm}$ b.g.l. does not seem to show any macroscopically observable pedogenic features at all (Rousseau et al., 2011, Fig. 3). Only for two levels of the likely end-MIS3 section (i.e. between ES5 and ES6a as well as in the basal part of ES6c), stagnic conditions were observed (Rousseau et al., 2011). However, the faster adaptable vegetation system shows a clear trisection (Rousseau et al., 2011):

1. the lowermost part of the so-called pollen-unit "bg1" (cf. Fig. 8 of Rousseau et al., 2011) between 635$390 \mathrm{~cm}$ b.g.l., including ES4b, shows more humid boreal and arcto-boreal forest steppe alternating with forest tundra as well as higher counts of mesophytic herbs and arboreal pollen and a higher diversity of arboreal pollen; pollen of Quercus was present in ES7, while Corylus was detected in ES8, ES6c and E5; the spore inventory of ES6c and ES6a point to excessive ground moisture in a cold climate; for ES7 and ES5, the absence of cryophytes is striking; this could possibly place E7 in the period prior to the Heinrich 3 event, and suggest a correlation of E5 with GIS4 or GIS3 towards the end of MIS3;

2. the upper part of pollen-unit "bg1" between 390 and $230 \mathrm{~cm}$ b.g.l., with considerably higher counts of grasses of up to $42 \%$ and a typical grass steppe; these could reflect the dryer conditions of a beginning MIS2;

3. the upper part of the Stayky profile between 230 and $70 \mathrm{~cm}$ b.g.l. corresponding to pollen-unit "bg2", for which counts and composition of arboreal pollen are much poorer than in the underlying "bg1" and which is characterized by typical periglacial steppe; this increase in aridity could reflect the terrestrial LGM conditions in the second half of MIS2, as suggested by the revised age model.

Thus, the changes in the vegetation history observed at Stayky seem to support the age model as suggested in the present paper, whereas the GSI-based event stratigraphy shows major unexplainable discrepancies with the IRSL chronology.

In order to substantiate the revised age model, additional chronometrical investigations would be desirable. For Stayky a validation of the IRSL dating could be performed by including OSL dating of quartz and ${ }^{14} \mathrm{C}$ dating of loess organic matter. As however, the stratigraphical resolution is much better at the reference profile at Nussloch, further dating should be considered also for the western European key section. Also, careful bio- and other stratigraphical comparison with other well analyzed profiles from the region, as, for example, the loess section at Arapovici (Molodkov and Bolikhovskaya, 2009; and literature quoted therein), could help to substantiate the chronostratigraphy for the Stayky loess section and to put a correlation with Greenland interstadials (GIS) on solid footing. Presently, long-distance correlations between the loess sites at Nussloch and Stayky should better be regarded as working hypotheses.

The chronometry supports a correlation of the uppermost MPG soils with GIS7-GIS5. If this hypothesis is doubted one or more of the following issues could be relevant:

- the ${ }^{14} \mathrm{C}$ ages for S2 and S3 from shell carbonate may overestimate the true ages of the soil formation so that the Sinzig Soils actually belong into the UPG and are not contemporaneous with LS,

- there may be an undetected error in the Nussloch stratigraphy with the thermokarst infilling (unit 15) being contemporaneous with LS (unit 20),

- the luminescence ages for Stayky may exhibit unusually large age underestimation.

These possibilities are presently not supported by the chronometry.

One last issue shall be addressed: the charm of the global marine and ice-core records is that they are quasi-continuous. As long as no (significant number of) ice layers are missing, the $\delta^{18} \mathrm{O}$ variations are quasi-continuously recorded and archived. If, however, the dust accumulation over the Arctic ice shield is taken as a reference proxy (cf. Rousseau 
et al., 2011), the record loses its original character and becomes (more like) an ordinary terrestrial archive, with all possible complications involved in sediment transport from source to sink. The reason is that the Greenland dust input is a semi-quantitative proxy for wind strength and dust mobilization in the East Asian deserts (e.g. Ruth, 2005), which may or may not be recorded completely (event number or frequency) and adequately (event intensity or magnitude) in the ice layers. Apart from that, it seems that the Greenland dust record is more appropriate for correlations with the Asian loess deposits, as they both might share the same source areas in East Asian deserts in western China and Inner Mongolia (e.g. Bory et al., 2002) ${ }^{8}$, unless the intention is to correlate the European loess sections via the vehicle of the Greenland ice shield dust proxy with the Asian loess deposits. From this latter consideration, it follows, that if future research can substantiate a correlation of the European loess sites with the Greenland dust record, then the European and the Asian loess deposits should also show such parallelizable signatures. Matching of central Asian loess records with dust records of Greenland ice cores was recently supported by Machalett et al. $(2011,2012)$.

\section{Summary and conclusion}

The event stratigraphy for the Stayky loess section is supported by four IRSL ages (Rousseau et al., 2011). If the IRSL ages are accepted, correlation of the suite of embryonic soils above the Vytachiv Soil presumably does not start with GIS7 but probably after GIS5. The lowermost incipient soils, likely encompassing ES8 to ES5/4b, probably developed during the final phase of MIS3. In that case, the transition from the terrestrial Middle to Upper Pleniglacial would have occurred during MIS3 (i.e. likely at the termination of GIS5). Therefore, the major pedozones, which include more mature and loamy soils in the Middle Pleniglacial and solely incipient soils in the Upper Pleniglacial, would not accord to the major isotope stages of the marine and ice-core archives. In this respect the general picture at the eastern European key loess section at Stayky in Ukraine seems to resemble that of the western European key section at Nussloch in southwestern Germany.

The western, more oceanic site (Nussloch: ca. $9^{\circ} \mathrm{E}, 49^{\circ} \mathrm{N}$ ) and the eastern, more continental site (Stayky: ca. $31^{\circ} \mathrm{E}$, $50^{\circ} \mathrm{N}$ ) are located at similar latitude. Therefore, it is imaginable that a common shift in palaeoecological conditions might have been correlated with respective advances of the northern European ice margin and corresponding changes in the North Atlantic climate circulation. Such early LGM ice advances at $<34 \mathrm{ka}$ (maximum luminescence age of glaciofluvial outwash deposits) were recently suggested for

\footnotetext{
${ }^{8}$ For ongoing investigations of sediment deposits of the Yellow River as likely source areas for loess on the Chinese loess plateau (cf. Stevens et al., 2012).
}

the Brandenburg ice marginal position in northeastern Germany (Lüthgens, 2011). As, however, terrestrial palaeoenvironmental MIS3 oscillations were apparently more susceptible to variations of the North Atlantic sea-surface temperature and corresponding sea-ice distribution than to the extent of the northern ice shield (Barron and Pollard, 2002), changes in the oceanic system might have been the actual trigger together with varying atmospheric dust load from the central Asian terrestrial sources acting as selfreinforcing effects of the Northern Hemispheric climate system (e.g. Machalett et al., 2011, 2012).

Since local (respectively regional) wind trajectories and vectors respond highly sensitive in a changing glacial climate, as, for example, documented by the GSI variations in the Nussloch and Stayky records (Antoine et al., 2001, 2009; Rousseau et al., 2011), wind might have been important for the marked change between MPG and UPG palaeosol character. This assumption is based on a model by Zech (2013), which states that the intensities of soil development are not merely a function of soil formation rates, but that increased dust input may "dilute" intensities, whereas decreased dust input may mimic increased soil formation rates. The Nussloch data allow a rough estimate of upper MPG versus lower UPG sedimentation rates. These are consistent with the Zech model, as they suggest sedimentation rates of ca. $\leq 0.5 \mathrm{~m} \mathrm{ka}^{-1}$ before GIS5 (unit 15/Huneborg IIunit 20/Denekamp) but ca. $1.5 \mathrm{~m} \mathrm{ka}^{-1}$ thereafter (unit $21-$ unit 24). Therefore it seems plausible that GIS4 and GIS3 are represented by soils which are less intensively developed than underlying MPG soils. The relatively high GSI values (ca. 1.3-1.6) of the likely GIS4 (CRha 2, unit 23) and GIS3 (CRha 3, unit 26) soils as compared to the Lohne Soil (unit 20; GSI ca. 0.6) are in agreement with increased aeolian input, if one assumes that post-sedimentary pedogenesis is not the dominant factor reducing the GSI values. Thus the Zech model could help explain why the terrestrial environments at Nussloch and Stayky seem to respond earlier (MPG-UPG boundary) than the marine and ice-core record (MIS3-MIS2 transition). This interpretation would be in agreement with Wunsch (2006) who considers changes in the palaeowind fields as a dominant trigger of environmental change, driving ocean circulation and the $\delta^{18} \mathrm{O}$ variations as documented in the ice-core records of the Greenland ice shield. Further, it would be in agreement with glacier advances in the Alps ca. 32-33 BP, as recently suggested for the Inn Valley (Spoetl et al., 2013). Fluvial-glacial melt-waters provide sediment sources for deflation and loess deposition.

Ultimately, it cannot be excluded that the loess-soil cycles observed in the terrestrial archive are not genetically correlated with the Dansgaard-Oeschger events or GIS, but that the two systems merely show similar high frequency rhythmicity (cf. Wunsch, 2006). The observation that the chronometry for Stayky does not support a simple one-toone correlation by merely counting soils and GIS could add to this skepticism. But if a genetic correlation between the 
ice core and the terrestrial archives is assumed, the Upper Pleniglacial part of the Stayky section provides good preconditions to investigate likely connections, as it does not show any obvious hiatuses (Rousseau et al., 2011), thus not pointing to sediment reworking or other perturbation possibly distorting the record. Therefore, loess accumulation in colder (i.e. windier) times interrupted by soil formation in warmer (i.e. less windy) times could possibly be the dominant eventsequence recorded in the pedosedimentary archive, justifying the assumption of a genetic interconnection.

The uppermost part of the Stayky loess section, possibly reaching down to $270 \mathrm{~cm} \mathrm{b.g.1.} \mathrm{and} \mathrm{in} \mathrm{this} \mathrm{case} \mathrm{including}$ ES2a/1, could date into the LGM, that is, the MIS2 period post-dating Heinrich 2 (MIS2b/2c). It is interesting to note that the revised age model for Stayky conforms to the independently revised age model for Nussloch (cf. Kadereit et al., 2013). For Nussloch, the necessity for a revision is even more obvious, as at the key section in western Europe GIS8 matches a well-datable thermokarst infilling which clearly predates the Lohne Soil. Due to the limited number of available ages, the revised interpretation for Stayky should be regarded as a working hypothesis, which could help guide future investigations along west-east loess transects through Europe and into Asia. It is essential that the terrestrial, and therefore highly incomplete, discontinuous and floating records are supported by solid chronometries as a necessary prerequisite for successful event-stratigraphical correlations. Based on these, promising approaches for advancing European loess research include (1) linking loess-palaeosol sequences with millennial-scale Dansgaard-Oeschger cycles (Rousseau et al., 2002), and (2) using a grain-size index (GSI) for the correlation of (distant) loess-palaeosol sections (Rousseau et al., 2011).

\section{Supplementary material related to this article is available online at http://www.clim-past.net/10/783/2014/ cp-10-783-2014-supplement.pdf.}

Acknowledgements. Fruitful discussion with Peter Kühn and Heinrich Thiemeyer on the nomenclature of the World Reference Base for Soils helped to classify the Nassböden at the Nussloch section in Germany according to WRB. Data underlying the Greenland-Hulu U/Th timescale illustrated in Fig. 3h and the ODP-Site 1002 record shown in Supplement - Fig. S2 are by courtesy of Olaf Jöris and Chronis Tzedakis. Volker Schniepp drew Fig. 2. Anatoly Molodkov kindly provided information on the Arapovichi loess section in Ukraine. We thank Scott D. Wilson for correcting the English.

Edited by: T. Kiefer

\section{References}

Alley, R. B., Meese, D. A., Shuman, C. A., Gow, A. J., Taylor, K. C., Grootes, P. M., White, J. W. C., Ram, M., Waddington, E. D., Mayewski, P. A., and Zielinski, G. A.: Abrupt increase in Greenland snow accumulation at the end of the Younger Dryas event, Nature, 362, 527-529, 1993.

Andersen, K. K., Svensson, A., Johnsen, S. J., Rasmussen, S. O., Biglera, M., Röthlisberger, R., Ruth, U., Siggaard-Andersen, M.-L., Steffensen, J. P., Dahl-Jensen, D., Vinther, B. M., and Clausen, H. B.: The Greenland Ice Core Chronology 2005, 15$42 \mathrm{ka}$, Part 1: constructing the time scale, Quaternary Sci. Rev., 25, 3246-3257, 2006.

Antoine, P., Rousseau, D.-D., Zöller, L., Lang, A., Munaut, A. V., Hatté, C., and Fontugne, M.: High-resolution record of the Last Interglacial-Glacial cycle in the loess palaeosol sequences of Nussloch (Rhine Valley - Germany), Quatern. Int., 76/77, 211229, 2001.

Antoine, P., Rousseau, D.-D., Moine, O., Kunesch, S., Hatté, C., Lang, A., Tissoux, H., and Zöller, L.: Rapid and cyclic aeolian deposition during the Last Glacial in European loess: a highresolution record from Nussloch, Germany, Quaternary Sci. Rev., 28, 2955-2973, 2009.

Antoine, P., Rousseau, D.-D., Degeai, J.-P., Moine, O., Lagroix, F., Kreutzer, S., Fuchs, M., Hatté, C., Gauthier, C., Svoboda, J., and Lisá, L.: High-resolution record of the environmental response to climatic variations during the Last InterglacialeGlacial cycle in Central Europe: the loess-palaeosol sequence of Dolní Vestonice (Czech Republic), Quaternary Sci. Rev., 67, 17-38, 2013.

Barron, E. and Pollard, D.: High-resolution climate simulations of oxygen isotope stage 3 in Europe, Quaternary Res., 58, 296-309, 2002.

Berger, G.: Thermoluminescence dating of the Pleistocene Old Crow tephra and adjacent loess near Fairbanks, Alaska, Can. J. Earth Sci., 24, 1975-1984, 1987.

Björck, S., Walker, M. J., Cwynar, L. C., Johnsen, S., Knudsen, K.-L., Lowe, J. J., Wohlfahrt, B., and INTIMATE Members: An event stratigraphy for the Last Termination in the North Atlantic region based on the Greenland ice-core record: a proposal by the INTIMATE group, J. Quaternary Sci., 13, 283-292, 1998.

Bory, A. J.-M., Biscaye, P. E., Svensson, A., and Grousset, F. E. Seasonal variability in the origin of recent atmospheric mineral dust at NorthGRIP, Greenland, Earth Planet. Sc. Lett., 196, 123 134, 2002.

Briant, R. M. and Bateman, M. D.: Luminescence dating indicates radiocarbon age underestimation in late Pleistocene fluvial deposits from eastern England, J. Quaternary Sci., 24, 916-927, 2009.

Bronk Ramsey, C.: OxCal Program v4.1, https://c14.arch.ox.ac.uk/ oxcal/OxCal.html, last access: 1 July 2012.

Buggle, B., Hambach, U., Glaser, B., Gerasimenko, N., Markovic, S., Glaser, I., and Zöller, L.: Stratigraphy, and spatial and temporal paleoclimatic trends in Southeastern/Eastern European loesspalaeosol sequences, Quatern. Int., 196, 86-106, 2009.

Dansgaard, W., Johnsen, S. J., Clausen, H. B., Dahl-Jensen, D., Gundestrup, N. S., Hammer, C. U., Hvidberg, C. S., Steffensen, J. P., Sveinbjörnsdottir, A. E., Jouzel, J., and Bond, G.: Evidence for general instability of past climate from a 250-kyr ice-core record, Nature, 364, 218-220, 1993. 
Fairbanks, R. G., Mortlock, R. A., Chiu, T.-C., Cao, L., Kaplan, A., Guilderson, T. P., Fairbanks, T. W., and Bloom, A. L.: Marine radiocarbon calibration curve spanning 0 to 50,000 years BP based on paired ${ }^{230} \mathrm{Th} /{ }^{234} \mathrm{U} /{ }^{238} \mathrm{U}$ and ${ }^{14} \mathrm{C}$ Dates on pristine corals, Quaternary Sci. Rev., 24, 1781-1796, 2005.

Fuchs, M., Rousseau, D.-D., Antoine, P., Hatté, C., Gauthier, C., Markovic, S., and Zöller, L.: Chronology of the Last Climatic Cycle (Upper Pleistocene) of the Surduk loess sequence, Vojvodina, Serbia, Boreas, 37, 66-73, 2008.

Fuchs, M., Kreutzer, S., Rousseau, D.-D., Antoine, P., Hatté, C., Lagroix, F., Moine, O., Gauthier, C., Svoboda, J., and Lisá, L.: The loess sequence of Dolní Vestonice, Czech Republic: A new OSL-based chronology of the Last Climatic Cycle, Boreas, 42 , 664-677, doi:10.1111/j.1502-3885.2012.00299.x, 2013.

GRIP Members - Greenland Ice-Core Project Members: Climate instability during the last Glacial period recorded in the GRIP ice core, Nature, 364, 203-208, 1993.

Guiter, F., Andrieu-Ponel, V., de Beaulieu, J.-L., Cheddadi, R., Calvez, M., Ponel, P., Reille, M., Keller, T., and Goeury, C.: The last climatic cycles in Western Europe: a comparison between long continuous lacustrine sequences from France and other terrestrial records, Quatern. Int., 111, 59-74, 2003.

Haase, D., Fink, J., Haase, G., Ruske, R., Pécsi, M., Richter, H., Altermann, M., and Jäger, K.-D.: Loess in Europe - its spatial distribution based on a European Loess Map, scale 1:2,500,000, Quaternary Sci. Rev., 26, 1301-1312, 2007.

Haesaerts, P., Borziac, I., Chekha, V. P., Chirica, V., Drozdov, N. I., Koulakovska, L., Orlova, L. A., van der Plicht, J., and Damblon, F.: Charcoal and wood remains for radiocarbon dating Upper Pleistocene loess sequences in Eastern Europe and Central Siberia, Palaeogeogr. Palaeocl., 291, 106-127, 2010.

Hatté, C., Pessenda, L. C., Lang, A., and Paterne, M.: Development of accurate and reliable ${ }^{14} \mathrm{C}$ chronologies for loess deposits: application to the loess sequence of Nußloch (Rhine Valley, Germany), Radiocarbon, 43, 611-618, 2001.

Hemming, S.: Heinrich events: Massive late Pleistocene detritus layers of the North Atlantic and their global climate imprint, Rev. Geophys., 42, RG1005, doi:10.1029/2003RG000128, 2004.

Higham, T.: European Middle and Upper Palaeolithic radiocarbon dates are often older than they look: problems with previous dates and some remedies, Antiquity, 85, 235-249, 2011.

Hoek, W. Z., Yu, Z. C., and Lowe, J. J.: INTegration of Ice-core, Marine, and Terrestrial records (INTIMATE): refining the record of the Last Glacial-Interglacial Transition, Quaternary Sci. Rev., 27, 1-5, 2008.

Huijzer, B. and Vandenberghe, J.: Climatic reconstruction of the Weichselian Pleniglacial in northwestern and central Europe, J. Quaternary Sci., 13/5, 391-417, 1998.

IUSS Working Group: World Reference Base for Soil Resources, WRB, revised edition, World Soil Resources Reports 103, Rome, 1-128, 2007.

Johnsen, S. J., Dahl-Jensen, D., Dansgaard, W., and Gundestrup, N.: Greenland palaeotemperatures derived from GRIP bore hole temperature and ice isotope profiles, Tellus, 47, 624-629, 1995.

Johnsen, S. J., Clausen, H. B., Dansgaard, W., Gundestrup, N., Hammer, C. U., Andersen, U., Andersen, K. K., Hvidberg, C. S., Dahl-Jensen, D., Steffensen, J. P., Shoji, H., Sveinbjornsdottir, A. E., White, J., Jouzel, J., and Fisher, D.: The $\delta^{18}$ O record along the Greenland Ice Core Project deep ice core and possible
Eemian climate instability, J. Geophys. Res., 102, 26397-26410, 1997.

Johnsen, S. J., Dahl-Jensen, D., Gundestrup, N., Steffensen, J. P., Clausen, H. B., Miller, H., Masson-Delmotte, V., Sveinbjornsdottir, A. E., and White, J.: Oxygen isotope and palaeotemperature records from six Greenland ice-core stations: Camp Century, Dye-3, GRIP, GISP2, Renland and NorthGRIP, J. Quaternary Sci., 16, 299-307, 2001.

Kadereit, A., Kühn, P., and Wagner, G. A.: Holocene relief and soil changes in loess-covered areas of south-western Germany: the pedosedimentary archives of Bretten-Bauerbach (Kraichgau), Quatern. Int., 222, 99-119, 2010.

Kadereit, A., Kind, C.-J., and Wagner, G. A.: The chronological position of the Lohne Soil in the Nussloch loess section - reevaluation for a European loess-marker horizon, Quaternary Sci. Rev., 59, 67-86, doi:10.1016/j.quascirev.2012.10.026, 2013.

Krbetschek, M. R., Rieser, U., and Stolz, W.: Optical dating: Some luminescence properties of natural feldspars, Radiat. Protect. Dosimet., 66, 407-412, 1996.

Kreutzer, S., Fuchs, M., Meszner, S., and Faust, D.: OSL chronostratigraphy of a loess-palaeosol sequence in Saxony/Germany using quartz of different grain sizes, Quatern. Geochronol., 10 102-109, 2012.

Lang, A.: Die Infrarot-Stimulierte-Lumineszenz als Datierungsmethode für holozäne Lössderivate, Ein Beitrag zur Chronometrie kolluvialer, alluvialer und limnischer Sedimente in Südwestdeutschland, Heidelberger Geographische Arbeiten, 103, 1-137, 1996.

Lang, A.: Optical dating of Late Glacial and Holocene sediments: test cases of water born sediments from central Europe, oral presentation, 4th International Conference on Geomorphology, 28 August-3 September 1997, Supplementi di Geografia Fisica e Dinamica Quaternaria, Supplemento III-1997, Bologna, Italy, p. 241, 1997.

Lang, A.,and Wagner, G. A.: Infrared stimulated luminescence dating of archaeosediments, Archaeometry, 38, 129-141, 1996.

Lang, A., Lindauer, S., Kuhn, R., and Wagner, G. A.: Procedures used for optically and infrared stimulated luminescence dating of sediments in Heidelberg, Ancient TL, 14, 7-11, 1996.

Lang, A., Hatté, C., Rousseau, D.-D., Antoine, P., Fontugne, M., Zöller, L., and Hambach, U., High-resolution chronologies for loess: comparing AMS ${ }^{14} \mathrm{C}$ and optical dating results, Quaternary Sci. Rev., 22/10-13, 953-959, 2003.

Lomax, J., Fuchs, M., Preusser, F., and Fiebig, M.: Luminescence based loess chronostratigraphy of the Upper Palaeolithic site Krems-Wachtberg, Austria, Quatern. Int., doi:10.1016/j.quaint.2012.10.037, in press, 2012.

Lüthgens, C.: The age of Weichselian main ice marginal positions in north-eastern Germany inferred from Optically Stimulated Luminescence (OSL) dating, PhD-thesis, http://www.diss. fu-berlin.de/diss/receive/FUDISS thesis_000000022882, Freie Universität Berlin, Berlin, 2011.

Machalett, B., Oches, E., Haam, E., Lai, Z. P., and Endlicher, W.: Late Pleistocene Aeolian Dust Dynamics in Central Asia and their Teleconnection with Short-term Climate Oscillations and Abrupt Climate Events in the Northern Hemisphere, XVIII INQUA Bern, Quaternary Sciences - the view from the mountains, 21-27 July 2011, Abstract 3073, Bern, 2011. 
Machalett, B., Oches, E., Haam, E., Lai, Z. P., and Endlicher, W.: Long Term Seasonality Changes and Short Term Climate Variability Recorded in Eurasian Loess: Examples from Serbia, Romania, Kazakhstan, and China, Geophys. Res. Abstr., 14, EGU2012-13305, 2012.

Markovic, S. B., Hambach, U., Catto, N., Jovanovica, M., Buggle, B., Machalett, B., Zöller, L., Glaser, B., and Frechen, M.: Middle and Late Pleistocene loess sequences at Batajnica, Vojvodina, Serbia, Quatern. Int., 198, 255-266, 2009.

Mauz, B., Bode, T., Mainz, E., Blanchard, H., Hilger, W., Dikau, R., and Zöller, L.: The luminescence dating laboratory at the University of Bonn: equipment and procedures, Ancient TL, 20/2, 53-61, 2002.

Meese, D. A., Gow, A. J., Grootes, P. M., Mayewski, P. A., Ram, M., Stuiver, M., Taylor, K. C., Waddington, E. D., and Zielinski, G. A.: The accumulation record from the GISP2 core as an indicator of climate change throughout the Holocene, Science, 266, 16801682, 1994.

Molodkov, A. and Bolikhovskaya, N.: Climate change dynamics in Northern Eurasia over the last $200 \mathrm{ka}$ : Evidence from molluscbased ESR-chronostratigraphy and vegetation successions of the loess-palaeosol records, Quatern. Int., 201, 67-76, 2009.

Necea, D., Fielitz, W., Kadereit, A., Andriessen, P. A. M., and Dinu, C.: Middle Pleistocene to Holocene fluvial terrace development and uplift-driven valley incision in the SE Carpathians, Romania, Tectonophysics, 602, 332-354, 2013.

Pirson, S., Flas, D., Abrams, G., Bonjean, D., Court-Picon, M., Di Modica, K., Draily, C., Damblon, F., Haesaerts, P., Miller, R., Rougier, H., Toussaint, M., and Semal, P.: Chronostratigraphic context of the Middle to Upper Palaeolithic transition: Recent data from Belgium, Quatern. Int., 259, 78-94, 2012.

Rasmussen, S. O., Andersen, K. K., Svensson, A. M., Steffensen, J. P., Vinther, B. M., Clausen, H. B., Siggaard-Andersen, M.L., Johnsen, S. J., Larsen, L. B., Dahl-Jensen, D., Bigler, M., Röthlisberger, R., Fischer, H., Goto-Azuma, K., Hansson, M.E., and Ruth, U.: A new Greenland ice core chronology for the last glacial termination, J. Geophys. Res., 111, D06102, doi:10.1029/2005JD006079, 2006.

Rasmussen, S. O., Seierstad, I. K., Andersen, K. K., Bigler, M., Dahl-Jensen, D., and Johnsen, S. J.: Synchronization of the NGRIP, GRIP, and GISP2 ice cores across MIS 2 and palaeoclimatic implications, Quaternary Sci. Rev., 27, 18-28, 2008.

Reimer, P. J., Baillie, M. G. L., Bard, E., Bayliss, A., Beck, J. W., Blackwell, P. G., Bronk Ramsey, C., Buck, C. E., Burr, G. S., Edwards, R. L., Friedrich, M., Grootes, P. M., Guilderson, T. P., Hajdas, I., Heaton, T. J., Hogg, A. G., Hughen, K. A., Kaiser, K. F., Kromer, B., McCormac, F. G., Manning, S. W., Reimer, R. W., Richards, D. A., Southon, J. R., Talamo, S., Turney, C. S. M., van der Plicht, J., and Weyhenmeyer, C. E.: Intcal09 and Marine09 Radiocarbon age calibration curves, 0-50,000 years cal BP, Radiocarbon, 51, 1111-1150, 2009.

Rieser, U. and Wang, N.: Dating polymineral finegrains: Experiences with the Single Aliquot Regenerative technique, poster presentation, 13th International Conference on Luminescence and Electron Spin Resonance Dating, 10-14 July 2011, Torun, Poland and Book of Abstracts, p. 169, 2011.

Rousseau, D. D., Gerasimenko, N. P., Matviischina, Z., and Kukla, G. J.: Late Pleistocene environments of the Central Ukraine, Quaternary Res., 56, 349-356, 2001.
Rousseau, D.-D., Antoine, P., Hatté, C., Lang, A., Zöller, L., Fontugne, M., Ben Othman, D., Luck, J. M., Moine, O., Labonne, M., Bentaleb, I., and Jolly, D.: Abrupt millennial climatic changes from Nussloch (Germany) Upper Weichselian eolian records during the Last Glaciation, Rapid Communication, Quaternary Sci. Rev., 21/14-15, 1577-1582, 2002.

Rousseau, D.-D., Kukla, G., and McManus, J.: What is what in the ice and the ocean?, Quaternary Sci. Rev., 25, 2025-2030, 2006.

Rousseau, D.-D., Antoine, P., Gerasimenko, N., Sima, A., Fuchs, M., Hatté, C., Moine, O., and Zoeller, L.: North Atlantic abrupt climatic events of the last glacial period recorded in Ukrainian loess deposits, Clim. Past, 7, 221-234, doi:10.5194/cp-7-2212011, 2011.

Ruth, U.: Mineral dust records from Greenland ice cores, PAGES Newsletter, 13/3, 17-18, 2005.

Ruth, U., Wagenbach, D., Bigler, M., Steffensen, J. P., Röthlisberger, R., and Miller, H.: High-resolution microparticle profiles at NorthGRIP, Greenland: case studies of the calcium-dust relationship, Ann. Glaciol., 35, 237-242, 2002.

Ruth, U., Wagenbach, D., Steffensen, J. P., and Bigler, M.: Continuous record of microparticle concentration and size distribution in the central Greenland NGRIP ice core during the last glacial period, J. Geophys. Res., 108, 1-1-1-12, 2003.

Schirmer, W.: Rhine loess at Schwalbenberg II - MIS 4 and 3, Eiszeitalter Gegenwart, 61/1, 32-47, doi:10.3285/eg.61.1.03, 2012.

Schönhals, E., Rohdenburg, H., and Semmel, A.: Ergebnisse neuerer Untersuchungen zur Würmlößgliederung in Hessen, Eiszeitalter Gegenwart, 15, 199-206, 1964.

Schulz, M.: On the 1470-year pacing of DansgaardOeschger warm events, Paeleoceanography, 17, 4-1-4-9, doi:10.1029/2000PA000571, 2002.

Semmel, A.: Ein Lößprofil bei Lisieux (Normandie) und seine stratigraphische Parallelisierung mit Würmlössen in Hessen, Eiszeitalter Gegenwart, 45, 59-61, 1995.

Shackleton, N. J., Hall, M. A., and Vincent, E.: Phase relationships between millennial-scale events 64,000-24,000 years ago, Paleoceanography, 15, 565-569, 2000.

Shackleton, N. J., Fairbanks, R. G., Chiu, T., and Parrenin, F.: Absolute calibration of the Greenland time scale: implications for Antarctic time scales and for $\Delta^{14} \mathrm{C}$, Quaternary Sci. Rev., 23, 1513-1522, 2004.

Skinner, L. C.: Revisiting the absolute calibration of the Greenland ice-core age-scales, Clim. Past, 4, 295-302, doi:10.5194/cp-4295-2008, 2008.

Sommer, R. and Zachos, F. E.: Fossil evidence and phylogeography of temperate species: 'glacial refugia' and post-glacial recolonization, J. Biogeogr., 36, 2013-2020, 2009.

Sowers, T., Bender, M., Labeyrie, L., Martinson, D., Jouzel, J., Raynaud, D., Pichon, J. J., and Korotkevich, Y. S.: A 135,000 year Vostok-SPECMAP common temporal framework, Paleooceanography, 8, 737-766, 1993.

Spoetl, C., Reimer, P. J., Starnberger, R., and Reimer, R. W.: A new radiocarbon chronology of Baumkirchen, stratotype for the onset of the Upper Würmian in the Alps, J. Quaternary Sci., 28, 552558, 2013. 
Stevens, T., Markovic, S., Zech, M., Hambach, U., and Sümegi, P.: Dust deposition and climate in the Carpathian basin over an independently dated last glacial-interglacial cycle, Quaternary Sci. Rev., 30, 662-681, 2011.

Stevens, T., Bird, A., Carter, A., Vermeesch, P., Watson, T., Lu, H., Andò, S., Garzanti, E., Cottam, M., Sevastjanova, I., and Rittner, M.: Rivers of dust - loess deposition and major rivers, Oral presentation and section in written form in book of abstracts, 36. Hauptversammlung, 16-20 September 2012, DEUQUA, Bayreuth, 2012.

Svensson, A., Andersen, K. K., Bigler, M., Clausen, H. B., DahlJensen, D., Davies, S. M., Johnsen, S. J., Muscheler, R., Rasmussen, S. O., Röthlisberger, R., Steffensen, J. P., and Vinther, B. M.: The Greenland Ice Core Chronology 2005, 15-42 ka, Part 2: Comparison to other records, Quaternary Sci. Rev., 25, 32583267, 2006.

Svensson, A., Andersen, K. K., Bigler, M., Clausen, H. B., DahlJensen, D., Davies, S. M., Johnsen, S. J., Muscheler, R., Parrenin, F., Rasmussen, S. O., R"othlisberger, R., Seierstad, I., Steffensen, J. P., and Vinther, B. M.: A 60000 year Greenland stratigraphic ice core chronology, Clim. Past, 4, 47-57, doi:10.5194/cp-4-472008, 2008.

Talamo, S., Hughen, K. A., Kromer, B., and Reimer, P.: Debates over Palaeolithic chronology - the reliability of ${ }^{14} \mathrm{C}$ is confirmed, J. Archaeol. Sci., 39, 2464-2467, 2012.

Terhorst, B., Appel, E., and Werner, A.: Palaeopedology and magnetic susceptibility of a loess-palaeosol sequence in southwest Germany, Quatern. Int., 76/77, 231-240, 2001.

Terhorst, B., Thiel, C., Peticzka, R., Sprafke, T., Frechen, M., Fladerer, F. A., Roetzel, R., and Neugebauer-Maresch, C.: Casting new light on the chronology of the loess/paleosol sequences in Lower Austria, Eiszeitalter Gegenwart, 60, 270-277, 2011.

Timar, A., Vandenberghe, D., Panaiotu, C. E., Panaiotu, C. G., Necula, C., Cosma, C., and van den Haute, P.: Optical dating of Romanian loess using fine-grained quartz, Quatern. Geochronol., 5, 143-148, 2010.

Törnqvist, T. E., Wallinga, J., Murray, A. S., de Wolf, H., Clevering, P., and de Gans, W.: Response of the Rhine-Meuse system (westcentral Netherlands) to the last Quaternary glacio-eustatic cycles: a first assessment, Global Planet. Change, 27, 89-111, 2000. van Huissteden, J. and Kasse, C.: Detection of rapid climate change in Last Glacial fluvial successions in The Netherlands, Global Planet. Change, 28, 319-339, 2001.

Vasiliniuc, S., Vandenberghe, D. A. G., Timar-Gabor, A., Cosma, C., and van den Haute, P.: Combined IRSL and post-IR OSL dating of Romanian loess using single aliquots of polymineral fine grains, Quatern. Int., 293, 15-21, 2013.

Wagner, B.: Spatial analysis of loess and loess-like sediments in the Weser-Aller catchment (Lower Saxony and Northern Hesse, NW Germany), Eiszeitalter Gegenwart, 60/1, 27-46, doi:10.3285/eg.60.1.02, 2011.

Wallinga, J., Murray, A., and Duller, G.: Underestimation of equivalent dose in single-aliquot optical dating of feldspars caused by preheating, Radiat. Meas., 32, 691-695, 2000.

Wang, Y. J., Cheng, H., Edwards, R. L., An, Z. S., Wu, J. Y., Shen, C.-C., and Dorale, J. A.: A High-Resolution Absolute-Dated Late Pleistocene Monsoon Record from Hulu Cave, China, Science, 294, 2345-2348, 2001.

Weninger, B. and Jöris, O.: ${ }^{14} \mathrm{C}$ age calibration curve for the last $60 \mathrm{ka}$ : the Greenland-Hulu U/Th timescale and its impact on understanding the Middle to Upper Paleolithic transition in Western Eurasia, J. Human Evol., 55, 772-781, 2008.

Weninger, B., Jöris, O., and Danzeglocke, U.: CalPal-2007, Cologne Radiocarbon Calibration \& Palaeoclimate Research Package, http://www.calpal.de/, last access: 15 May 2012.

Wiesenberg, G. L. B.: Lateral and depth variation of loess organic matter overprint related to rhizoliths - Revealed by lipid molecular proxies and X-ray tomography, Catena, 112, 72-85, doi:10.1016/j.catena.2012.11.011, 2014.

Wunsch, C., Abrupt climate change: An alternative view, Quaternary Res., 65, 191-203, 2006.

Zech, R.: Loess is the accumulation of dust, not evidence for aridity, Geophys. Res. Abstr., 15, EGU2013-11263, 2013.

Zöller, L. and Semmel, A.: 175 years of loess research in Germany - long records and "unconformities", Earth-Sci. Rev., 45, 19-28, 2001. 